\title{
Synthesis and Characterization of Some New Pyrazoline Compounds Derived from Azo Chalcones
}

\author{
Aso Hameed Hasan ${ }^{1}$, Baram Ahmed Jaff ${ }^{2}$ \\ 1 Department of Chemistry, College of Science, University of Garmian- Kalar \\ 2 Department of Science, Charmo University-Chamchamal-Sulaimani
}

\begin{abstract}
1-[4-(2,4-Bis-benzy loxy-pheny lazo)-phenyl]-ethanone ( $\mathbf{A z})$ was prepared via diazotization of 4-aminoacetophenone and coupling of the product with resorcinol, then it was benzylated with benzyl bromide to give (Bz). The prepared benzloxy-azo compound $(\mathbf{B z})$ was reacted with differently substituted benzaldehy de to obtain azo-chalcone (Ch1Ch6). These chalcones were reacted with hydrazine hydrate to yield azo-pyrazoline compounds (Py1-Py6). The structures of prepared compounds were characterized by FT-IR and ${ }^{1} \mathrm{H}$ NMR spectroscopies.
\end{abstract}

\subsection{Introduction}

Chalcones are well-known precursors for synthesizing various heterocyclic compounds. This is due to the presence of reactive $\alpha, \beta$-unsaturated keto group which could be reacted with diazoalkanes [1] or with hydrazine hydrate [2,3] in order to synthesize pyrazoline compounds. Pyrazoline derivatives are heterocyclic compounds which is widely used in pharmaceutical and agrochemical research.

These compounds have substantial biological activities such as antimicrobial [4], antifungal [5], antidepressant [6], immunosuppressive [7], anticonvulsant [8], anti-tumour [9], antiamoebic [10], antibacterial [11] and anti-inflammatory [12]. In addition, pyroazolines have optical brighteners and whiteners properties [13]. Furthermore, these compounds show attractive fluorescent properties in the detection of some metal cations [14] and they are excellent hole transport and emissive layer materials in electrolu minescence devices $[15,16]$. Therefore, the focus of the present work is to synthesize some new azo-pyrazoline derivatives. Pyrazoline compounds could be synthesised by several methods such as condensation of a variety of substituted chalcones with hydrazine and its derivatives, which is the commonly used method $[17,18]$.

\subsection{Experimental}

\subsection{Reagents and Solvents}

All chemicals, reagents, and solvents obtained from Sigma-Aldrich and Fluka.

\subsection{Instrumentation}

All FT-IR spectra for the products were recorded using Shimadzu FT-IR spectrophotometer. All ${ }^{1} \mathrm{H}$ NMR spectra for the products measured with a Bruker Avance $(400 \mathrm{MHz})$ spectrometer in deuterated dimethyl sulfoxide $\left(\mathrm{CD}_{3} \mathrm{SOCD}_{3}\right)$ as a solvent. The chemical shifts were measured in parts per million (ppm).

\subsection{Synthetic procedures for the Precursor}

\subsubsection{Synthesis of 1-(4-((2,4-dihydroxyphenyl)diazenyl)phenyl) ethan-1-one (Az) (19): Diazotization of 4-Aminoacetophenone}


4-Aminoacetophenone (4.05 g, $0.03 \mathrm{~mol})$ was dissolved in $\mathrm{HCl}$ solution $(24 \mathrm{~mL}, 3 \mathrm{M})$ in a beaker. The solution was heated gently on heating mantle in order to dissolve the starting material completely. The mixtu re cooled to $0{ }^{\circ} \mathrm{C}$ and to this mixture, $\mathrm{NaNO}_{2}$ solution $(30 \mathrm{~mL}, 1 \mathrm{M})$ added and stirred. The reaction temperature maintain below $10{ }^{\circ} \mathrm{C}$.

\section{Coupling Reaction}

Resorcinol (3.03 g, $0.03 \mathrm{~mol})$ was dissolved in $\mathrm{NaOH}$ solution $(60 \mathrm{~mL}, 1 \mathrm{M})$ in another beaker. The reaction mixture was cooled to $0{ }^{\circ} \mathrm{C}$ and then diazonium salt solution added dropwises and stirred. During the progress of the reaction, the color of the reaction mixture was changed and solidified. After addition completed, the temperature raised to room temperature and stirred for 10 minutes. The product was filtered and then purified by recrystallization from water and ethanol.

${ }^{1} \mathrm{H}$ NMR (400 MHz, $\mathrm{CD}_{3} \mathrm{SOCD}_{3}, \delta$ ): 3.38 (s, 3H, $\mathrm{COCH}_{3}$ ), 6.36-6.51 (dd, 2H, H-13 and H-14), 7.68 (s, 1H, H-11), 7.94-8.08 (m, 4H, H-4, H-5, H-7 and H-8), 12.40 (s, 2H, OH). FT-IR (c m $\left.{ }^{-1}\right): 3296$ (OH), 1656 $(\mathrm{C}=\mathrm{O}), 1597(\mathrm{C}=\mathrm{C})$. All physical properties are outlined in table 1 .

\subsubsection{Synthesis of 1-(4-((2,4-bis(benzyloxy)phenyl)diazenyl)phenyl) ethan-1-one (Bz) [20]:}

1-(4-((2,4-dihydro xyphenyl)diazenyl)phenyl)ethan-1-one $(2.57 \mathrm{~g}, 0.01 \mathrm{~mol})$, ben zyl bro mide $(3.77 \mathrm{~g}, 0.022$ $\mathrm{mol})$, anhydrous $\mathrm{K}_{2} \mathrm{CO}_{3}(8.29 \mathrm{~g}, 0.06 \mathrm{~mol})$ and ethanol $(50 \mathrm{~mL}, 96 \%)$ added to a flask and refluxed for 6 $\mathrm{hr}$. The reaction mixture cooled to room temperature and then poured into water, solid immediately was obtained. Subsequently, the product was filtered, washed several times with cold water and dried. The product was recrystallized from a mixture of (xylene: ethanol, 2:8) to yield $\mathbf{B z}$ as orange crystals.

${ }^{1} \mathrm{H}$ NMR (400 MHz, $\left.\mathrm{CD}_{3} \mathrm{SOCD}_{3}, \delta\right): 3.36\left(\mathrm{~s}, 3 \mathrm{H}, \mathrm{COCH}_{3}\right), 5.21-5.37\left(\mathrm{~s}, 4 \mathrm{H}, \mathrm{OCH}_{2}\right), 6.75-811(\mathrm{~m}, 24 \mathrm{H}$, Ar-H). FT-IR $\left(\mathrm{cm}^{-1}\right): 3059$ (C-H aro matic), $2873(\mathrm{C}-\mathrm{H}$ aliphatic), $1674(\mathrm{C}=\mathrm{O}), 1597(\mathrm{C}=\mathrm{C}), 1251(\mathrm{C}-\mathrm{O})$. The some physicalproperties are outlined in table 1 .

\subsection{Synthesis of Chalcones (Ch1-Ch6)}

(Ch1-Ch6) were prepared according to the modified procedure [21]. Bz (10 mmol) and substituted aldehyde $(10 \mathrm{mmol})$ were dissolved in ethanol $(10 \mathrm{~mL}, 96 \%), \mathrm{NaOH}(0.4 \mathrm{~g})$ was added, then stirred at room temperature overnight. The reaction mixture was poured into crushed ice and then acidifies with dilute $\mathrm{HCl}$. The precip itate was filtered, washed with water, and then dried. The product was recrystallized from ethanol. Some physical properties are outlined in table 1.

\subsection{1. (3E)-1-(4-((2,4-bis(benzyloxy)phenyl)diazenyl)phenyl)-4-phenyl but-3-en-1-one (Ch1):}

${ }^{1} \mathrm{H}$ NMR $\left(400 \mathrm{MHz}, \mathrm{CD}_{3} \mathrm{SOCD}_{3}, \delta\right): 5.25\left(\mathrm{~s}, 4 \mathrm{H}, \mathrm{OCH}_{2}\right), 7.02-8.38(\mathrm{~m}, 24 \mathrm{H}, \mathrm{Ar}-\mathrm{H}$ and $\alpha, \beta-\mathrm{H})$. FT-IR $\left(\mathrm{cm}^{-1}\right): 1660(\mathrm{C}=\mathrm{O}) 1597(\mathrm{C}=\mathrm{C})$.

2.4.2. (3E)-1-(4-((2,4-bis(benzyloxy)phenyl)diazenyl)phenyl)-4-(4 fluorophenyl) but-3-en-1 -one (Ch2): ${ }^{1} \mathrm{H}$ NMR $\left(400 \mathrm{MHz}, \mathrm{CD}_{3} \mathrm{SOCD}_{3}, \delta\right): 5.24\left(\mathrm{~s}, 4 \mathrm{H}, \mathrm{OCH}_{2}\right), 6.95-7.74(\mathrm{~m}, 23 \mathrm{H}, \mathrm{Ar}-\mathrm{H}$ and $\alpha, \beta-\mathrm{H})$. FT-IR $\left(\mathrm{cm}^{-1}\right): 1664(\mathrm{C}=\mathrm{O}), 1597(\mathrm{C}=\mathrm{C})$.

2.4.3. (3E)-1-(4-((2,4-bis(benzyloxy)phenyl) diazenyl)phenyl)-4-(4-methoxyphenyl) but-3-en-1-one (Ch3):

${ }^{1} \mathrm{H}$ NMR $\left(400 \mathrm{MHz}, \mathrm{CD}_{3} \mathrm{SOCD}_{3}, \delta\right): 3.36\left(\mathrm{~s}, 3 \mathrm{H}, \mathrm{OCH}_{3}\right), 5.12\left(\mathrm{~s}, 4 \mathrm{H}, \mathrm{OCH}_{2}\right), 7.16-8.15(\mathrm{~m}, 23 \mathrm{H}, \mathrm{Ar}-\mathrm{H}$ and $\alpha, \beta-\mathrm{H})$. FT-IR $\left(\mathrm{cm}^{-1}\right): 1658(\mathrm{C}=\mathrm{O}) 1598(\mathrm{C}=\mathrm{C})$.

2.4.4. (3E)-1-(4-((2,4-bis(benzyloxy)phenyl)diazenyl)phenyl)-4-(p-tolyl)but-3-en-1-one (Ch4):

${ }^{1} \mathrm{H} \mathrm{NMR}\left(400 \mathrm{MHz}, \mathrm{CD}_{3} \mathrm{SOCD}_{3}, \delta\right): 5.22\left(\mathrm{~s}, 4 \mathrm{H}, \mathrm{OCH}_{2}\right), 3.36\left(\mathrm{~s}, 3 \mathrm{H}, \mathrm{CH}_{3}\right), 6.20-7.94(\mathrm{~m}, 23 \mathrm{H}, \mathrm{Ar}-\mathrm{H}$ and $\alpha, \beta-\mathrm{H})$. FT-IR $\left(\mathrm{cm}^{-1}\right): 1660(\mathrm{C}=\mathrm{O}), 1600(\mathrm{C}=\mathrm{C})$.

2.4.5. (3E)-4-(2-(benzyl oxy)phenyl)-1-(4-((2,4-bis(benzyloxy) phenyl) diazenyl) phenyl) but-3-en-1-one (Ch5):

${ }^{1} \mathrm{H}$ NMR $\left(400 \mathrm{MHz}, \mathrm{CD}_{3} \mathrm{SOCD}_{3}, \delta\right): 5.41\left(\mathrm{~s}, 9 \mathrm{H}, \mathrm{OCH}_{2}\right), 6.95-8.36(\mathrm{~m}, 27 \mathrm{H}, \mathrm{Ar}-\mathrm{H}$ and $\alpha, \beta-\mathrm{H})$. FT-IR $\left(\mathrm{cm}^{-1}\right): 1658(\mathrm{C}=\mathrm{O}), 1597(\mathrm{C}=\mathrm{C})$. 
2.4.6. (3E)-1-(4-((2,4-bis(benzyloxy)phenyl)diazenyl)phenyl)-4-(2-chlorophenyl)but-3-en-1-one (Ch6):

${ }^{1} \mathrm{H}$ NMR $\left(400 \mathrm{MHz}, \mathrm{CD}_{3} \mathrm{SOCD}_{3}, \delta\right): 5.26\left(\mathrm{~s}, 4 \mathrm{H}, \mathrm{OCH}_{2}\right), 7.09-8.45(\mathrm{~m}, 23 \mathrm{H}, \mathrm{Ar}-\mathrm{H}$ and $\alpha, \beta-\mathrm{H})$. FT-IR $\left(\mathrm{cm}^{-1}\right): 1672(\mathrm{C}=\mathrm{O}), 1597(\mathrm{C}=\mathrm{C})$.

\subsection{Synthetic procedures for the Pyrazolines (Py1-Py6)}

Chalcones $(0.01 \mathrm{~mol})$ in ethanol $(20 \mathrm{~mL})$ and $\mathrm{NaOH}(0.8 \mathrm{~g})$, hydrazine hydrate $(0.025 \mathrm{~mol}, 80 \%)$ were added to a flask and then refluxed for 6-7 hr. The reaction mixture was cooled and maintained at room temperature. The resulting solid was filtered and dried. The product was recrystallized from ethanol [21]. The some physical properties are outlined in table 1.

2.5.1.3-(4-((2,4-bis(benzyl oxy)phenyl)diazenyl)phenyl)-5-phenyl-4,5-dihydro-1 H-pyrazole (Py1):

${ }^{1} \mathrm{H}$ NMR $\left(400 \mathrm{MHz}, \mathrm{CD}_{3} \mathrm{SOCD}_{3}, \delta\right): 1.23$ (s, 1H, H-8), 3.35 (s, 1H, H-7), $5.21\left(\mathrm{~s}, 4 \mathrm{H}, \mathrm{OCH}_{2}\right), 6.75-8.12$ $\left(\mathrm{m}, 23 \mathrm{H}, \mathrm{Ar}-\mathrm{H}\right.$ and N-H). FT-IR $\left(\mathrm{cm}^{-1}\right): 1660(\mathrm{C}=\mathrm{N}), 1597(\mathrm{C}=\mathrm{C})$.

2.5.2. 3-(4-((2,4-bis (benzyl oxy)phenyl) diazenyl) phenyl) -5-(4-fluorophenyl)-4,5-dihydr 0-1 H-pyrazole (Py2):

${ }^{1} \mathrm{H}$ NMR $\left(400 \mathrm{MHz}, \mathrm{CD}_{3} \mathrm{SOCD}_{3}, \delta\right): 1.22$ (s, 1H, H-8), 3.22 (s, 1H, H-7), $5.21\left(\mathrm{~s}, 4 \mathrm{H}, \mathrm{OCH}_{2}\right), 6.74-8.10$ (m, $22 \mathrm{H}$, Ar-H and N-H). FT-IR $\left(\mathrm{cm}^{-1}\right)$ : $1664(\mathrm{C}=\mathrm{N}), 1597(\mathrm{C}=\mathrm{C})$.

2.5.3. 3-(4-( (2,4-bis (benzyloxy) phenyl)di azenyl $)$ phenyl $)$-5-(4-me thoxyphenyl) -4,5-dihydro-1 Hpyrazole (Py3):

${ }^{1} \mathrm{H}$ NMR (400 MHz, $\mathrm{CD}_{3} \mathrm{SOCD}_{3}, \delta$ ): 1.22 (s, 1H, H-8), 3.99 (s, 1H, H-7), 5.21 (s, 4H, OCH $), 3.79$ (s, 3H, $\left.\mathrm{OCH}_{3}\right)$, 7.12-8.07 (m, $22 \mathrm{H}, \mathrm{Ar}-\mathrm{H}$ and N-H). FT-IR $\left(\mathrm{cm}^{-1}\right)$ : $1658(\mathrm{C}=\mathrm{N}), 1604(\mathrm{C}=\mathrm{C})$.

2.5.4. 3-(4-((2,4-bis (benzyl oxy)phenyl) diazenyl)phenyl) -5-(p-tolyl)-4,5-dihydro-1 H-pyrazole (Py4):

${ }^{1} \mathrm{H}$ NMR (400 MHz, $\mathrm{CD}_{3} \mathrm{SOCD}_{3}, \delta$ ): 1.23 (s, 1H, H-8), 3.33 (s, 1H, H-7), 5.22 (s, 4H, OCH $), 2.32$ (s, 3H, $\left.\mathrm{CH}_{3}\right), 7.06-8.02\left(\mathrm{~m}, 22 \mathrm{H}, \mathrm{Ar}-\mathrm{H}\right.$ and N-H). FT-IR $\left(\mathrm{cm}^{-1}\right): 1660(\mathrm{C}=\mathrm{N}), 1600(\mathrm{C}=\mathrm{C})$.

2.5.5. 3-(4-((2,4-bis (benzyloxy)phenyl)diazenyl)phenyl)-5-(2-((3-nitrobenzyl)oxy) phenyl)-4,5dihydro-1 H-pyrazole (Py5):

${ }^{1} \mathrm{H}$ NMR $\left(400 \mathrm{MHz}, \mathrm{CD}_{3} \mathrm{SOCD}_{3}, \delta\right): 1.22$ (s, 2H, H-8), 3.33 (s, 1H, H-7), $5.21\left(\mathrm{~s}, 6 \mathrm{H}, \mathrm{OCH}_{2}\right), 6.50-7.87$ $\left(\mathrm{m}, 26 \mathrm{H}, \mathrm{Ar}-\mathrm{H}\right.$ and N-H). FT-IR $\left(\mathrm{cm}^{-1}\right): 1658(\mathrm{C}=\mathrm{N}), 1600(\mathrm{C}=\mathrm{C})$.

2.5.6. 3-(4-((2,4-bis(benzyloxy)phenyl)di azenyl)phenyl)-5-(2-chl orophenyl)-4,5-dihydr o-1 H-pyrazole (Py6):

${ }^{1} \mathrm{H}$ NMR (400 MHz, $\mathrm{CD}_{3} \mathrm{SOCD}_{3}, \delta$ ): 1.22 (s, 1H, H-8), 3.32 (s, $\left.1 \mathrm{H}, \mathrm{H}-7\right), 5.20$ (s, 4H, $\mathrm{OCH}_{2}$ ), 6.74-8.10 (m, $23 \mathrm{H}$, Ar-H and N-H). FT-IR $\left(\mathrm{cm}^{-1}\right)$ : $1672(\mathrm{C}=\mathrm{N}), 1597(\mathrm{C}=\mathrm{C})$.

Table 1: Physical properties for the synthesized compounds

\begin{tabular}{|l|l|l|l|l|l|}
\hline No. & Comp. & (G) group & Chem. formula & $\begin{array}{l}\text { Molecular } \\
\text { weight }\end{array}$ & Yield (\%) \\
\hline 1 & $\mathrm{Az}$ & - & $\mathrm{C}_{14} \mathrm{H}_{12} \mathrm{~N}_{2} \mathrm{O}_{3}$ & 256.257 & 79 \\
\hline 2 & $\mathrm{Bz}$ & - & $\mathrm{C}_{28} \mathrm{H}_{24} \mathrm{~N}_{2} \mathrm{O}_{3}$ & 436.502 & 62.8 \\
\hline 3 & $\mathrm{C} 1$ & $\mathrm{H}$ & $\mathrm{C}_{36} \mathrm{H}_{30} \mathrm{~N}_{2} \mathrm{O}_{3}$ & 524.608 & 78.2 \\
\hline 4 & $\mathrm{C} 2$ & $4-\mathrm{F}$ & $\mathrm{C}_{36} \mathrm{H}_{29} \mathrm{FN}_{2} \mathrm{O}_{3}$ & 542.599 & 93.7 \\
\hline 5 & $\mathrm{C} 3$ & $4-\mathrm{OCH}_{3}$ & $\mathrm{C}_{37} \mathrm{H}_{32} \mathrm{~N}_{2} \mathrm{O}_{4}$ & 554.634 & 82.5 \\
\hline 6 & $\mathrm{C} 4$ & $4-\mathrm{CH}_{3}$ & $\mathrm{C}_{37} \mathrm{H}_{32} \mathrm{~N}_{2} \mathrm{O}_{3}$ & 538.635 & 96.2 \\
\hline 7 & $\mathrm{C} 5$ & $2-\left(3-\mathrm{NO}_{2}\right.$-benzoxy) & $\mathrm{C}_{43} \mathrm{H}_{3}{ }_{6} \mathrm{~N}_{2} \mathrm{O}_{4}$ & 675.728 & 68.1 \\
\hline 8 & $\mathrm{C} 6$ & $2-\mathrm{Cl}$ & $\mathrm{C}_{36} \mathrm{H}_{29} \mathrm{ClN}_{2} \mathrm{O}_{3}$ & 559.053 & 63.7 \\
\hline 9 & Py1 & $\mathrm{H}$ & $\mathrm{C}_{36} \mathrm{H}_{32} \mathrm{~N}_{4} \mathrm{O}_{2}$ & 538.638 & 97.5 \\
\hline 10 & Py2 & $4-\mathrm{F}$ & $\mathrm{C}_{35} \mathrm{H}_{29} \mathrm{FN}_{4} \mathrm{O}_{2}$ & 556.64 & 82.7 \\
\hline 11 & Py3 & $4-\mathrm{OCH}$ & $\mathrm{C}_{36} \mathrm{H}_{32} \mathrm{~N}_{4} \mathrm{O}_{3}$ & 568.67 & 72.3 \\
\hline 12 & Py4 & $4-\mathrm{CH}$ & $\mathrm{C}_{36} \mathrm{H}_{32} \mathrm{~N}_{4} \mathrm{O}_{2}$ & 552.67 & 91.5 \\
\hline 13 & Py5 & $2-\left(3-\mathrm{NO}_{2}\right.$-benzoxy) & $\mathrm{C}_{42} \mathrm{H}_{35} \mathrm{~N}_{5} \mathrm{O}_{5}$ & 689.758 & 92 \\
\hline 14 & Py6 & $2-\mathrm{Cl}$ & $\mathrm{C}_{35} \mathrm{H}_{29} \mathrm{ClN}_{4} \mathrm{O}_{2}$ & 573.09 & 64.3 \\
\hline
\end{tabular}

Where benzoxy: $\mathrm{OCH}_{2} \mathrm{C}_{6} \mathrm{H}_{4}$ 


\subsection{Results and Discussion}

The present study was designed to synthesize and characterization of some new pyrazoline derivatives with azo-linkage and benzyloxy moiety. All target compounds have been synthesized in moderate to high yields. The synthetic process of the new target compound is outlined in scheme 1 .<smiles>CC(=O)c1ccc(N=Nc2ccc(O)cc2O)cc1</smiles><smiles>[R]C(C)=O</smiles>

\section{Scheme 1: Synthetic Steps of the Pyrzaoline Derivatives}

The precursor 1-(4-((2,4-bis(benzyloxy)phenyl)diazenyl)phenyl)ethan-1-one (Bz) has prepared successfully via diazotization of 4-aminoacetophenone and reacted with resorcinol as a coupling agent to afford 1-(4-((2, 4-dihydroxyphenyl)diazenyl)phenyl)ethan-1-one (Az). The next step was benzylation of $\mathbf{A z}$ with benzyl bromide to form $\mathbf{B z}$ was carried out in the presence of anhydrous $\mathrm{K}_{2} \mathrm{CO}_{3}$ and ethanol as a solvent. The structure was confirmed by FT-IR and ${ }^{1} \mathrm{H}$ NMR spectroscopies. In the FT-IR spectrum of $\mathbf{B z}$, a broad band at $3296 \mathrm{~cm}^{-1}$ and a singlet peak at $12.40 \mathrm{ppm}$ in the ${ }^{1} \mathrm{H}$ NMR spectrum disappear which is good evidence that the benzylation reaction was successful.

The Chalcones were synthesized as intermed iate compounds via Claisen-Schmidt condensation of $\mathbf{B z}$ with several substituted benzaldehyde in alcoholic $\mathrm{NaOH}$ solution. The processes were succeeded to yield chalcones. The most important evidence for the formation of chalcones is the shifting of carbonyl group bands to approximately $1660 \mathrm{~cm}^{-1}$ and exhibited the characteristic of deshielding for $\alpha$ - and $\beta$ - protons at approximately (6.95-8.45 ppm) in ${ }^{1} \mathrm{H}$ NMR spectrum.

The target compounds synthesized were chalcone derivatives subjected to hydrazine hydrate and reflexed. In the FT-IR spectra for (Py1-Py6) co mpounds the dis appearance of $(\mathrm{C}=\mathrm{O})$ group band for enone system is robust evidence for the formation of imine in five membered cyclic system [22]. The ${ }^{1} \mathrm{H}$ NMR spectra displayed signals assigned to N-H at approximately 7.87-8.10 ppm. 


\subsection{Conclusion}

In this study, the results show that new azo-pyrzaoline derivatives synthesized successfully by multiple steps in good yields. It can be concluded that achieve many organic compounds and used in different fields, for example, medicine and Industry of dyes. All the synthesized compounds were characterized by FT-IR and ${ }^{1} \mathrm{H}$ NMR spectroscopies.

\section{Acknowledgement}

The authors would like to acknowledge the help provided by Assistant Prof. Dr Farouq Emam hawiz, and the continual Support of Department of Chemistry, College of Science, Garmian University.

\section{References}

1. A. Lévai, Monatshefte für Chemie/Chemical Monthly, 1995, 126 (11), 1245-1251.

2. M. A. Ali, M. Shaharyar and A. A. Siddiqui, European journal of medicinal chemistry, 2007, 42 (2), 268-275.

3. M. Amir, H. Kumar and S. A. Khan, Bioorganic \& medicinal chemistry letters, 2008, 18 (3), 918-922

4. K. Ramalingam, G. X. Thyvelikakath, K. D. Berlin, R. W. Chesnut, R. A. Brown, N. N. Durham and D. Van der Helm, Journal of medicinal chemistry, 1977, 20 (6), 847-850.

5. S. S. Korgaokar, P. H. Patil, M. J. Shah and H. H. Parekh, Indian J Pharm Sci, 1996, 58, 222-225.

6. Y. R. Prasad, A. L. Rao, L. Prasoona, K. Murali and P. R. Kumar, Bioorganic \& medicinal chemistry letters, 2005, 15 (22), 5030-5034.

7. J. G. Lombardino and I. G. Otterness, Journal of medicinal chemistry, 1981, 24 (7), 830-834.

8. Z. Özdemir, H. B. Kandilci, B. Gümüşel, Ü. Çalış, and A. A. Bilgin, European journal of medicinal chemistry, 2007, 42 (3), 373-379.

9. E. C. Taylor and H. H. Patel, Tetrahedron, 1992, 48 (37), 8089-8100.

10. A. Budakoti, M. Abid and A. Azam, European journal of medicinal chemistry, 2006, 41 (1), 63-70.

11. G. Turan-Zitouni, A. Özdemir and K. Güven, Archiv der Pharmazie, 2005, 338 (2-3), 96-104.

12. O. A. Fathalla, M. E. A. Zaki, S. A. Swelam, S. M. Nofal and W. I. El-Eraky, Acta poloniae pharmaceutica, 2003, 60 (1), 51-60.

13. P. Singh, J. S. Negi, , G. J. Nee Pant, , M. S. Rawat and A. Budakoti, Molbank, 2009, 2009 (3), M614.

14. B. Lu, J. Zhang, M. Wang, Y. Zhou and X. Chen, Chinese Journal of Chemistry, 2012, 30 (6), $1345-$ 1350.

15. V. Ramkumar and P. Kannan, Journal of Luminescence, 2016, 169, 204-215.

16. V. Ramkumar and P. Kannan, Optical Materials, 2015, 46, 605-613.

17. L. Knorr, European Journal of Inorganic Chemistry, 1893, 26 (1), 100-103.

18. V. G. Thakare and K. N. Wadodkar, Chemischer Informationsdienst, 1986, 17 (44).

19. M. C. Hamzacebi, S. Rollas, S. G. Küçükgüzel and B. K. Kaymakçığlu, Arkivoc, 2008, 12, 188-194.

20. F. E. Hawaiz and M. K. Samad, Journal of Chemistry, 2012, 9 (3), 1613-1622.

21. G. Turan-Zitouni, A. Özdemir and K. Güven, Archiv der Pharmazie, 2005, 338 (2-3), 96-104.

22. A. J. Hussein, ZANCO Journal of Pure and Applied Sciences. 2015, 27 (1), 51-58. 


\section{Appendix}

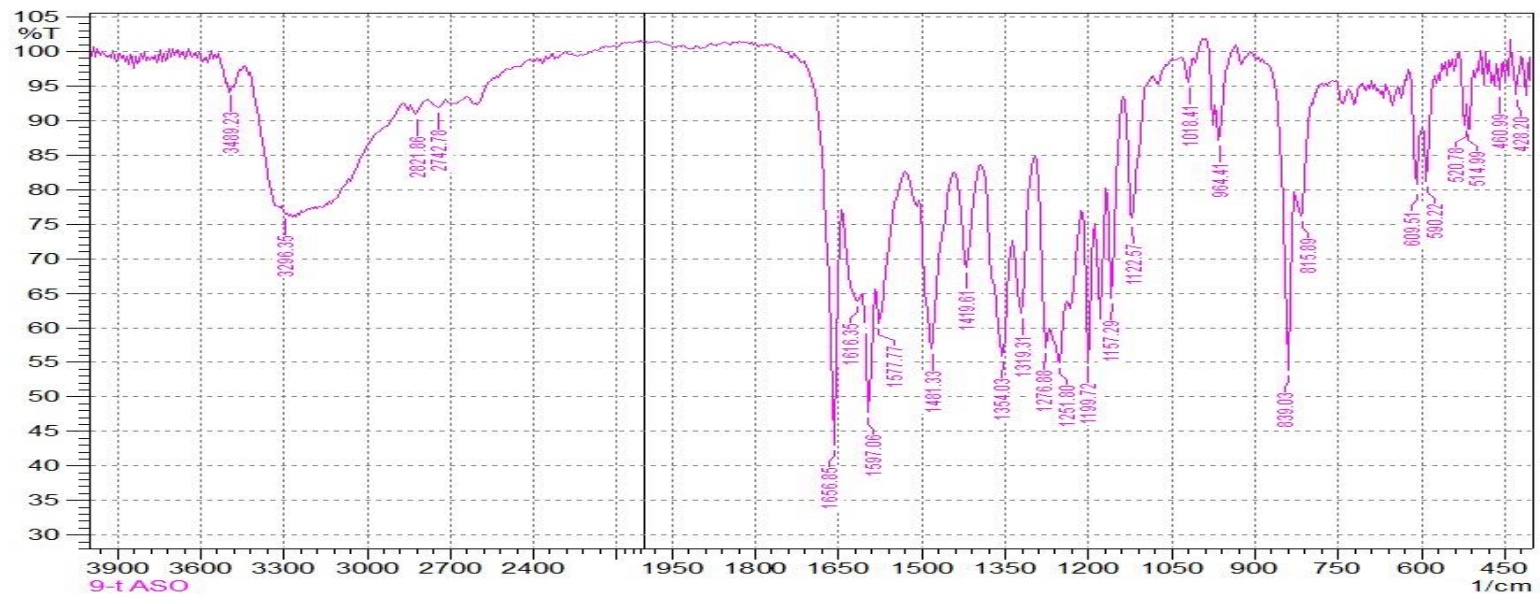

Figure 1: FT-IR spectrum of compound Az.

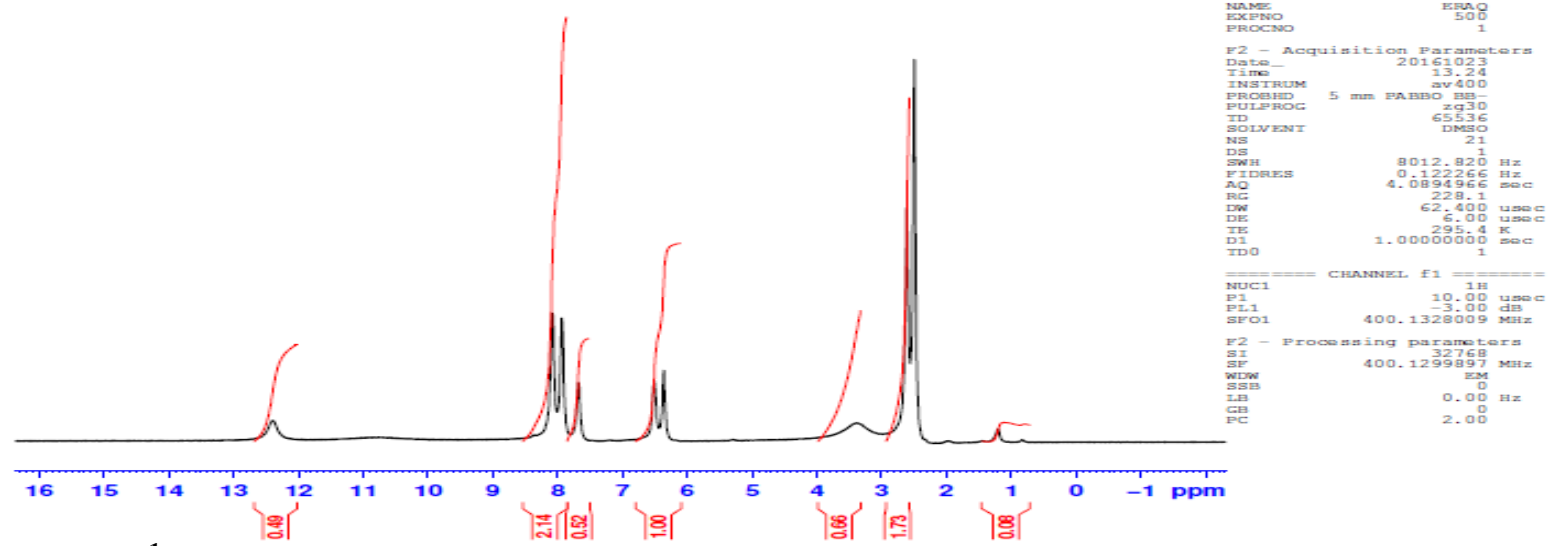

Figure 2: ${ }^{1} \mathrm{H}$ NMR spectrum of compound Az.

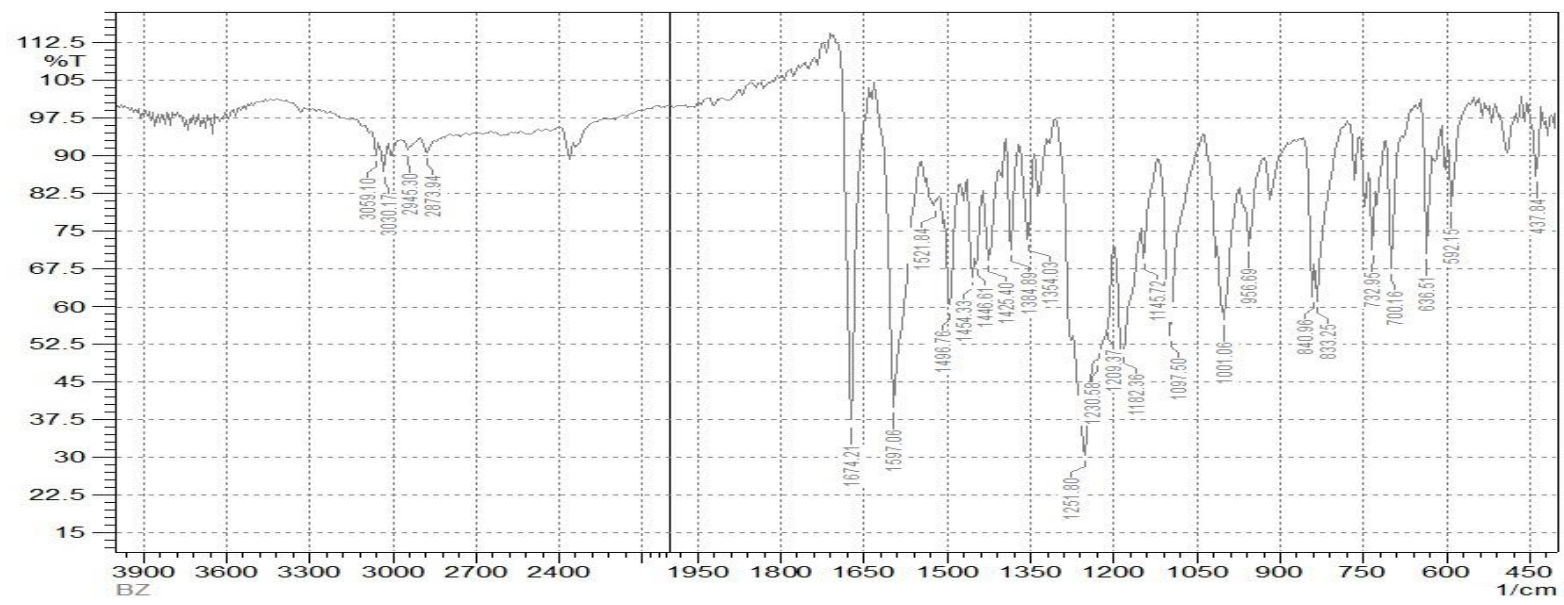

Figure 3: FT-IR spectrum of compound bz. 


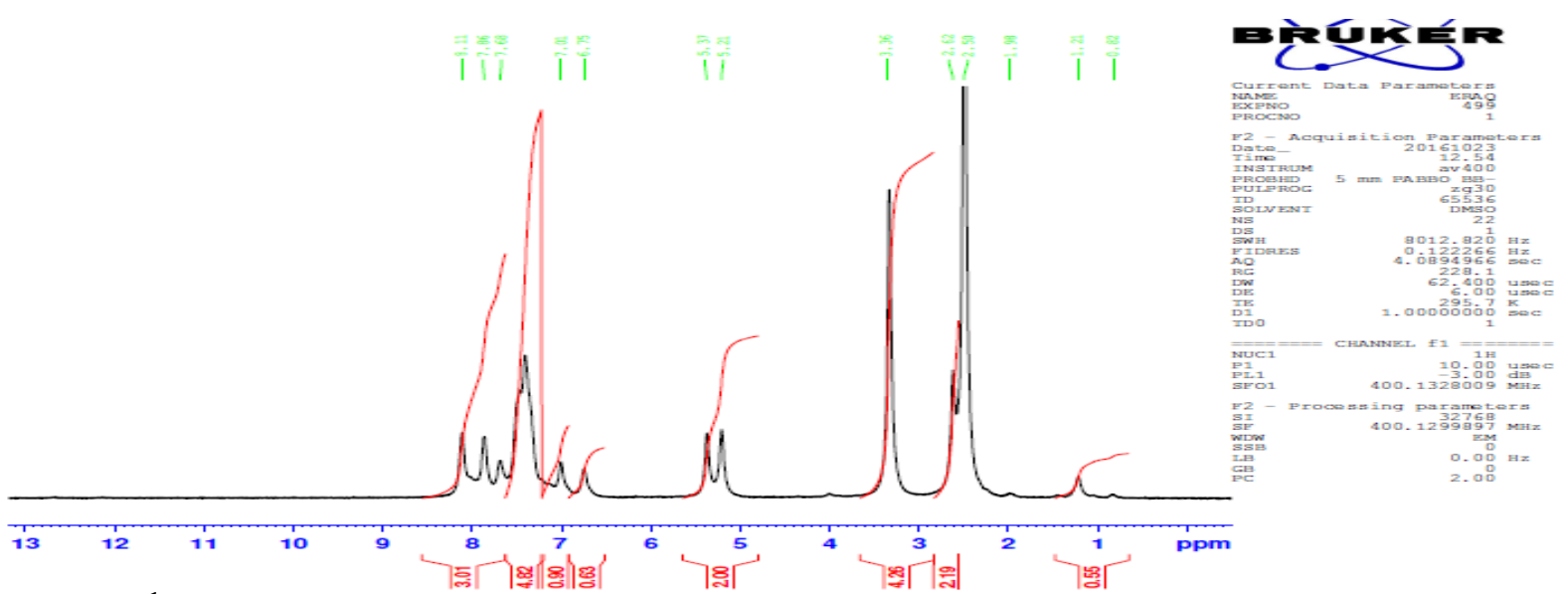

Figure 4: ${ }^{1} \mathrm{H}$ NMR spectrum of compound $\mathrm{Bz}$.

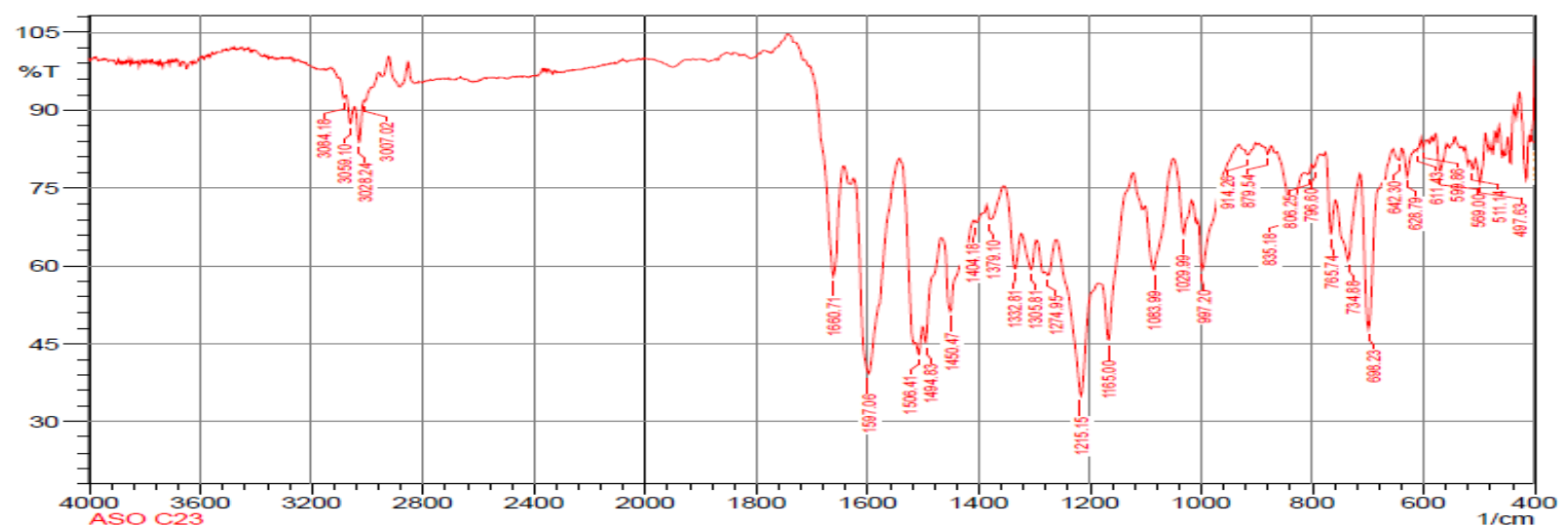

Figure 5: FT-IR spectrum of compound CH1.

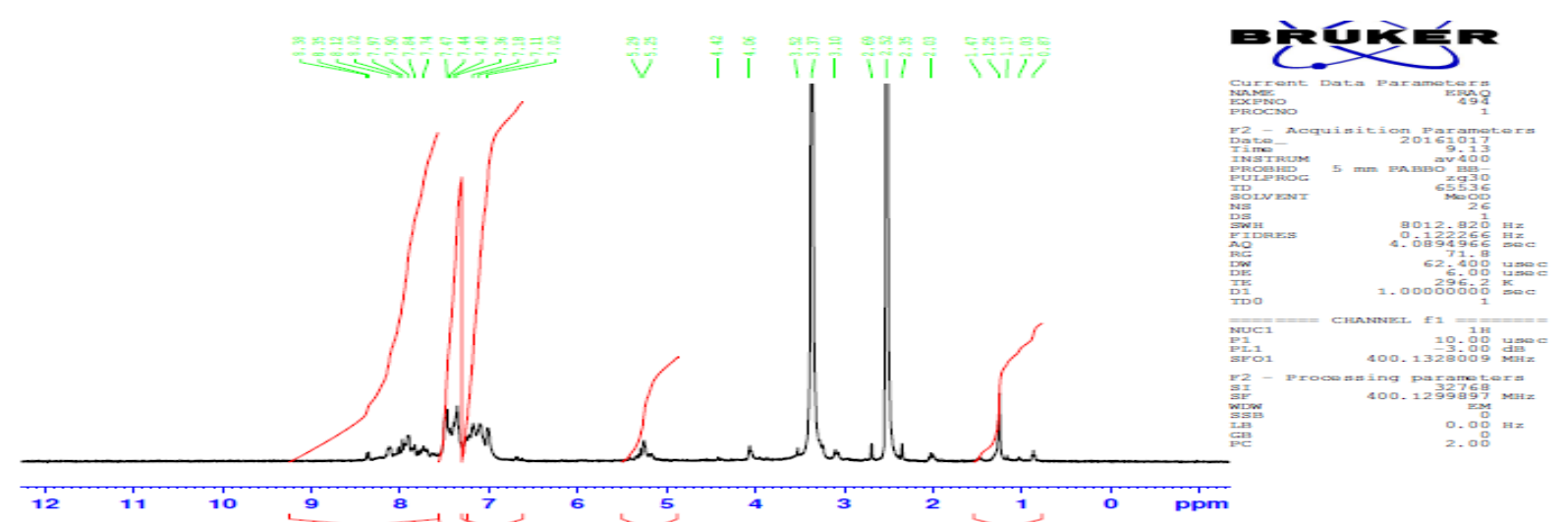

Figure 6: ${ }^{1} \mathrm{H}$ NMR spectrum of compound $\mathrm{CH}$. 


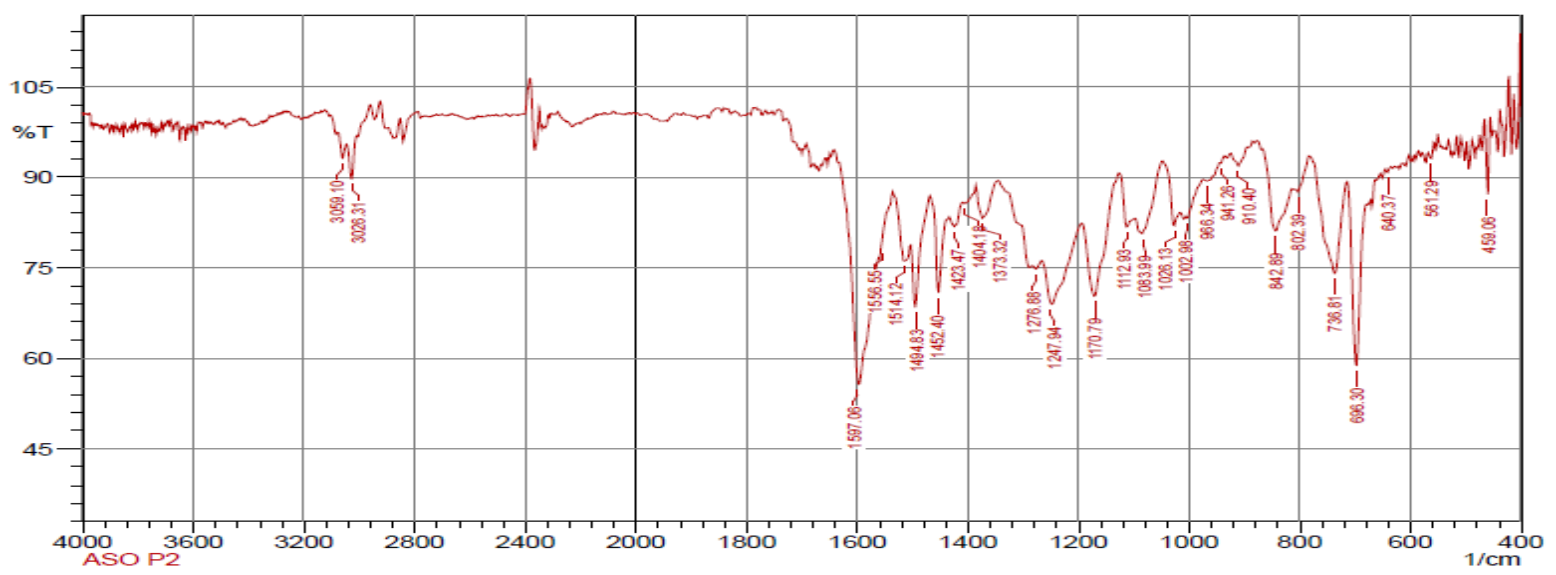

Figure 7: FT-IR spectrum of compound Py1

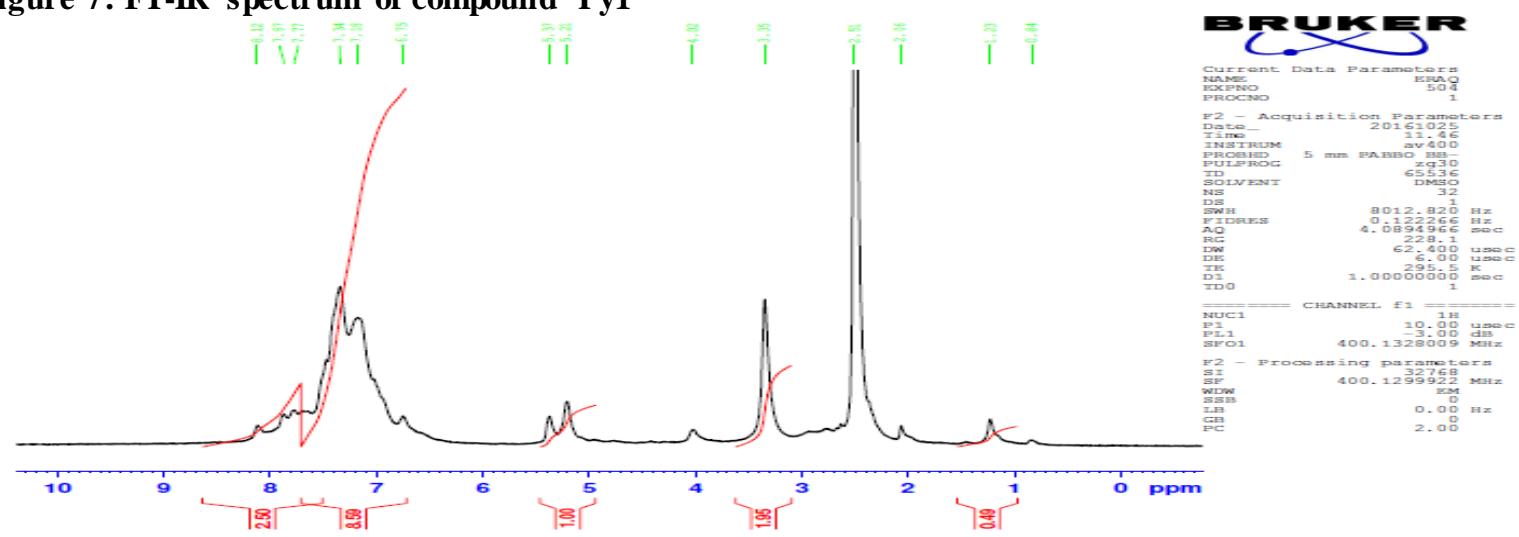

Figure 8: ${ }^{1} \mathrm{H}$ NMR spectrum of compound Py1 